\title{
THE DISRUPTION OF MYTHOLOGICAL SPACE
}

Sena Lee

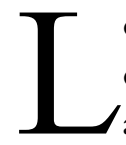

ouis Marin defines mythological space as a space where 'anything can happen [...] the most extraordinary act, the most exceptional adventures, the wildest situations'. In mythological space, there is 'surprise and eruption of events, [...] irreducible newness on which our attention hangs'. ${ }^{\mathrm{I}}$ Marin was not thinking of space as a narrative with a sequence of actions and consequences. Instead he was thinking of utopic space, an unreachable imaginary space emerging from countless unknown possibilities. What he did not conceive was what would happen when the real world entered into this imaginary space. What would happen when utopia was no longer out of reach? I turn to a cycle of mythological frescoes executed in I6I6 by the Bolognese painter Domenichino at the Villa Aldobrandini in Frascati and acquired by the National Gallery in 1958 (figure I). These are now a set of separate panels, which were transferred from fresco to canvas by the National Gallery, and thus no longer distinguishable from all other portable paintings that constitute the National Gallery's collection. ${ }^{2}$ This move from fresco to canvas is not insignificant to the history of mythological painting, which depended on claims of permanence for its prestigious status, and which by the seventeenth century was challenged by the emergence of an art market characterized by transportability and exchange. At this point in time, mobility and instability altered what mythological painting could be, and thus what mythological space could become. In effect, the transfer from wall to panel erased the traditional claims of Domenichino's cycle of painting. What I hope to show is that it also obscured the innovative strategies through which mythological painting addressed the challenge of the art market.

Of ten mythological scenes, seven - and a fragment of an eighth - are at the National Gallery while the others remain at the Villa Aldobrandini. The original setting of the frescoes was a gallery known as the Stanza of 


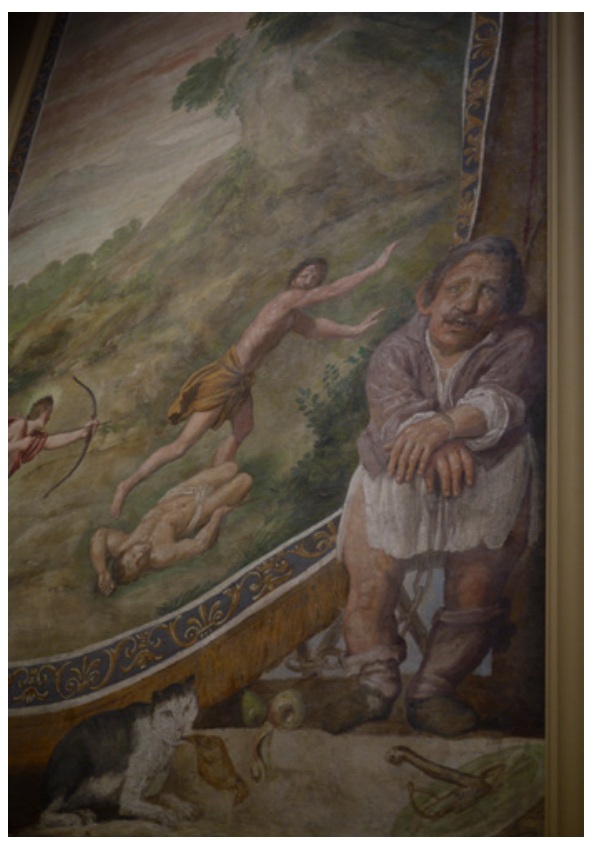

Figure Ia and Ib Display of

Domenichino's cycle of frescoes from The Villa Aldobrandini in the National Gallery, c.I6I6, fresco, transferred to canvas and mounted on board. (C) The National Gallery London. Courtesy of The National Gallery, London. Photo: the author.

(a)

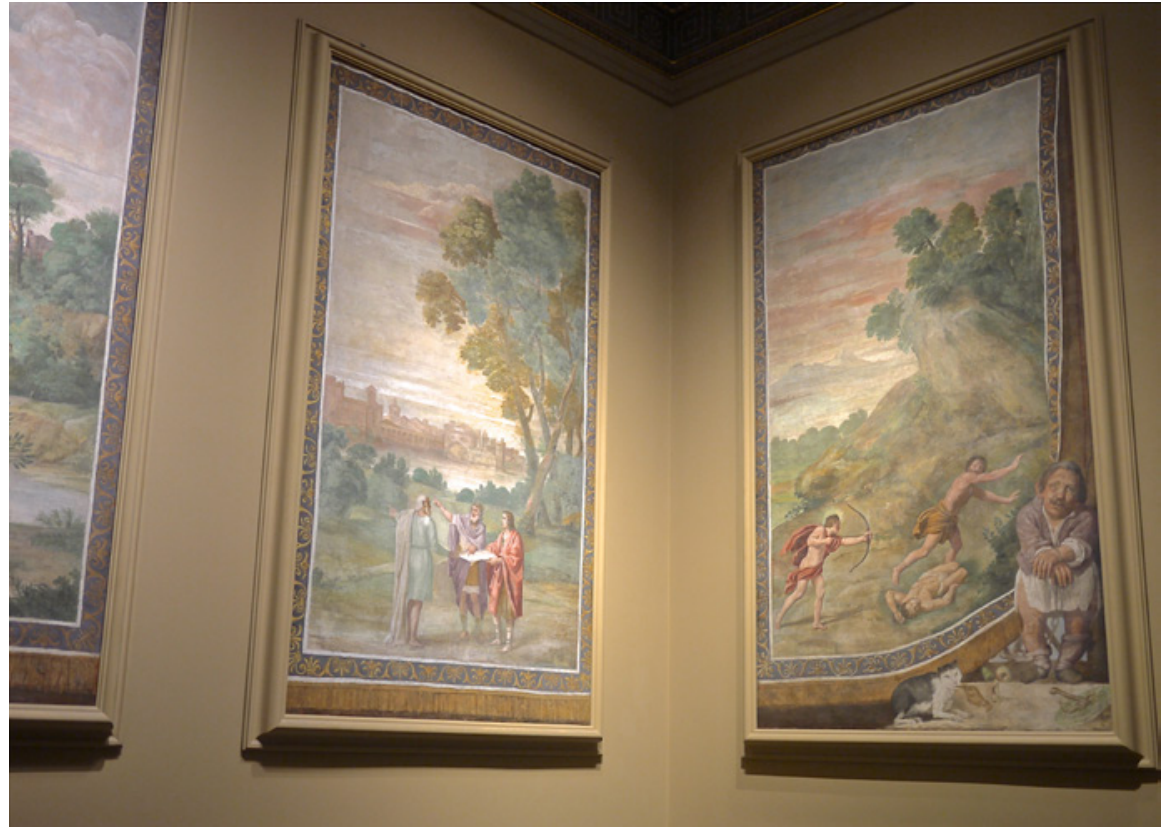

(b) 
Apollo. ${ }^{3}$ The architecture, transformed through painting, multicoloured mosaics and stucco, joined forces with fresco as the marker of a country villa of a prominent noble family. The association between architecture and fresco had given fresco the claim of being the most elite form of art, able to change the appearance of architecture at will. ${ }^{4}$ In the Stanza of Apollo, the ceiling is illusionistically painted to resemble an open bower and the walls as if hung with tapestries and paintings. This calls up the tradition of tapestries as the most desirable and prestigious form of decoration, especially in relation to their function in drafty palaces and villas. The tapestries, with borders that act somewhat like a picture frame, both suggest an exclusive internal space for painting and continue the illusion of painting's ability to transform the architectural space itself into a site of visual wonder. Walking around the room, one might become absorbed by idyllic landscapes in which small figures play out mythological events and produce a space that has potential in the sense that Louis Marin vividly discussed.

It is not surprising that the frescoes depict episodes from the story of Apollo, and all are drawn from Ovid's Metamorphoses. ${ }^{5}$ Transformation was in fact what fresco shared with mythology, and each compounded the effects of the other. The Metamorphoses was the ancient source most frequently used for Roman and Greek mythological subjects, especially for amorous stories of transformation that came to be linked to spaces of leisure in villas, and garden galleries in city palaces. ${ }^{6}$ These themes of transformation challenged painting to come up with illusionistic pictorial effects and increasingly extended just what painting could produce beyond the visible. ${ }^{7}$ The issue of space has always held a challenge in mythological painting conceived as transformative. Unlike history painting, in which the narrative dominates the background, in mythological painting the question of space is central to the transformative aspects of mythology itself. Mythology's transformative potential is what made mythological space so unpredictable and so laden with possibility, and what simultaneously generated an awareness about painting. Apollo and Daphne, in which the nymph Daphne is transformed into a laurel tree, and thus into nature, brought forth debates about the successes and failures of painting in dealing with this difficult scene of transformation; in the Villa Aldobrandini, it also contributed to the idea of the transformation of the inside of the villa into its outside gardens. ${ }^{8}$ Fresco painting and ancient mythology worked together in the transformation of permanent architectural space, but their 
effects were not contained within the decoration itself. Domenichino's frescoes, following a tradition of acknowledging the specificity of its setting, mirror both the internal and external spaces of the villa.

Fresco's tradition of self-reflection is invariably based on an awareness of its relation to the space in which it is situated and which completes its effects. For instance, opposite the window on the right wall is the tapestry with the scene of Apollo Killing Cyclops, which is partly opened and shows a reflection of the window on the opposite side. ${ }^{9}$ The landscapes that appear in the illusionistic tapestries and paintings represent the insertion of the lavish gardens of the villa into the Stanza of Apollo, there to reiterate that external idealized setting. If one takes the idea of mythological space seriously, certainly as Louis Marin did, then perhaps the dominant scholarly interpretation of mythological fresco can be brought into question. It been considered as an attempt to bring mythology into a contemporary terrain, but is it not, perhaps, mythology that is enacting on the landscape, and not the other way around. The mythological space does not merely reflect the existing garden, rather it shows it to be one of many layers, layers that the frescoes themselves reveal and more importantly conceal. The implication is that fresco's illusionism tricks the eye and can make one see what is not there and not see what is there. This kind of self-aware mythological space could not be produced outside its intended site and is perhaps less about the denial of time, as is frequently claimed about mythological painting, but rather about a layering of imaginative space that depends on embodied time, yet is also always seeking to undermine it. ${ }^{\text {IO }}$

In the case of Domenichino's cycle, the layering contains further surprises, beyond what Marin envisioned. Turning again to the right wall, and the tapestry with the scene of Apollo Killing Cyclops, one notices that the tapestry that has been pulled back reveals more than the window on the opposite side (figure 2). In this unexpected gesture something else emerges - the figure of a man, characterized by his short stature, humble attire and his chained hands. This figure is traditionally called a dwarf, and I will use this terminology aware of its problems. The appearance of this man proves something of a disruption, and adds another layer, this one also unexpected but in a different way. ${ }^{\mathrm{II}}$ The presence of a dwarf in the court is hardly surprising; after all, representation of the dwarf served to expand the idealized notion of the court and its idealized space. The ruler's perfection depended on increasingly complicated ideas of 


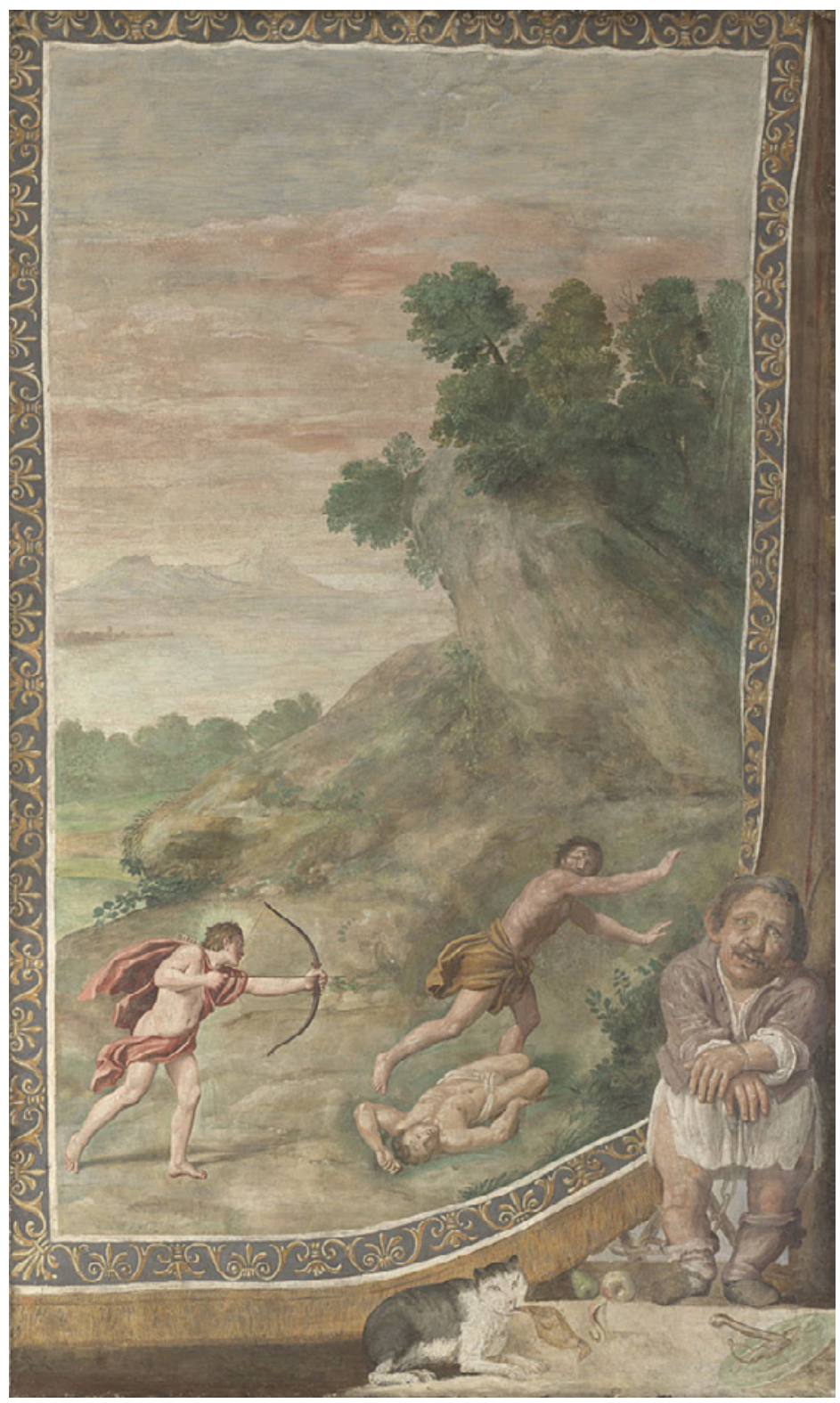

Figure 2 Domenichino, Apollo Killing Cyclops, c.I6I6, fresco, transferred to canvas and mounted on board, 3 I $6.3 \times 190.4 \mathrm{~cm}$, The National Gallery, London. (C) The National Gallery, London. Photo: The National Gallery, London. 
breeding and improving on nature's imperfections. ${ }^{\mathrm{I} 2}$ But here the trope of the dwarf turns into something else. The figure of the dwarf is not part of the mythological narrative. Yet he is, by far, the most meticulously and vividly painted part of the frescoes, to the extent that its status in relation to the mythological space becomes an urgent issue. The scale of the dwarf's body overwhelms that of Apollo and other mythological characters in the tapestry itself. The ambiguous yet perhaps scornful expression on the dwarf's face, like his bodily presence, brings to the scene a subtle sense of mockery.

The location of the dwarf, at the edge of the tapestry, is worth comparing to another well-known representation of a dwarf that in Raphael's frescoes, The Vision of Constantine (c. I 520) in the 'Sala di Constantino' in the Vatican Palace. ${ }^{13}$ The dwarf in Raphael's painting is within the narrative scene although his marginality is indicated by his location at the edge of the painted tapestry. Raphael's dwarf imitates and perhaps mocks the heroic Roman soldier who is at the centre of this fresco. His helmet is awkwardly placed, his muscular body full of heroic intent, but lacking in the dexterity and agility that defines the idealized soldier. Domenichino's dwarf, in contrast, is not an inversion of the idealized courtier or the idealized mythological figure; rather his appearance, attitude and costume seem to come from an entirely different world. He is dressed not as a courtly dwarf but in the humble disheveled clothing of a character from a painting of everyday life. This kind of 'low-life' character is invariably defined through a conjunction of grotesque body and unkempt attire, accompanied by an ambiguous attitude that for the viewer makes for an unsettling encounter. Moreover, the dwarf is no longer inside the image but seems to have emerged from behind it. Where has he come from if he is outside pictorial space?

According to Giovanni Battista Passeri, Domenichino's contemporary biographer, the unexpected presence of the dwarf can be explained as an incident of court life. Passeri, who met Domenichino at the Villa in I634 and undoubtedly discussed the Stanza with him, is very specific about the dwarf's location. ${ }^{14}$ He tells that the dwarf was actually a court member of the Aldobrandini palace who was known to dance and display himself with pride. ${ }^{\mathrm{Is}}$ Cardinal Pietro Aldobrandini wanted to punish the dwarfs insolence so he commissioned Domenichino to include him at the specific location on the wall where the dwarf would habitually dance. This image was to be unveiled at the moment in which the dwarf was dancing, as a curtain 
covering the painting was drawn back revealing an unflattering image of the dwarf. According to Passeri, 'everyone laughed so heartily that it was like a concert'. ${ }^{16}$ Passeri expands, 'seeing himself derided and mocked in this way, the dwarf became speechless, refusing to sit at the table despite the command of the Princes'. ${ }^{17}$

The implication is that the dwarf has emerged from an account of life in the court, much as the mythological space is produced through textual authority. But the account offers an interesting clue, which is the importance it gives to the gesture of opening a curtain to reveal something concealed behind. At the court event, the presumptuous dwarf was humiliated when a grotesque image of himself, dressed in ragged clothes and chained, was revealed. But this grotesque character is not simply behind the real curtain, it is itself revealed through the opening of a second curtain, in this case the tapestry that is part of mythological space. What is this dwarf 'uncovering'? What is hidden behind the tapestry? What is concealed behind the surface perfection of courtly life?

Directly in front of the dwarf, where the tapestry reveals a hidden space, we notice an unusual array of objects. A cat quickly snatches a quail, perhaps from a nearby plate with leftovers, and an apple and a pear lie abandoned, partly peeled. The objects seem to be neither fully-realized as discrete objects nor fully integrated into a coherent image. What is this space revealed by the movement of the tapestry? It cannot be explained in relation to a narrative, not the mythological narrative and certainly not the narrative recounted by Passeri. This foreground space remains ambiguous, perhaps 'un-grounded' or 'pre-formed' in relation to the illusionism of the tapestries. For example, it is unclear where the cat is sitting; is it the lower step from the ground where the dwarf and the fruits stand? Or is it in another register, one in which the rules of linear perspective are overturned? So what is this space that suddenly has become visible by pulling up the tapestry? It includes, as already noted, the lower right side of a window frame, and it is to this frame that the dwarf is chained. This window, barely visible but clearly present through the links of the chains, now comes into question. Is this a reflection of the window on the other side caused by the movement of the tapestry? Or is this a window hidden by the tapestry? Domenichino's spatial arrangements have generated discussion in terms of the ruptured boundary between real space and painted space. ${ }^{I 8}$ It has been suggested that the lifted tapestry, revealing the window 
behind, is an extension of the traditional scheme of painting where the eye is encouraged to imagine the space beyond the 'window'. ${ }^{\text {I9 }}$ In other words, a window within a window.

What is intriguing is that the dwarf is literally chained to a reflection of the window; an assertion of the illusions of place but also a mocking of the belief in these illusions. Of course the fact that the entrapped figure resembles someone from a new kind of marketable painting, in fact the most mobile form of painting, cannot but suggest a provocation. At the very location where the tapestry is revealed to be a superficial covering, stands the dwarf. The illusion of mythological space is interrupted by the tapestry that is pulled aside to reveal what is behind, behind the tapestry, behind pictorial space, behind the surface of courtly life. Instead of the idea of surface that gives onto an empty space, what we have are layers, and the space opened up by the dwarf revealed as a different kind of layering. ${ }^{20}$

\section{Debates on mythological space}

The relation of mythological space to the actual world was always at stake and some painting, Titian's work in particular, defined this in terms of simultaneity. His mythological paintings frequently assert the imaginary as a space by showing historical figures occupying the same space as mythological figures but entirely oblivious to their presence. Yet the two spaces do intersect, as something of the spirit of one seeps into the other, such as we see in The Bacchanal of the Andrians (c.I523). In this painting, two women in contemporary dress seem to occupy a separate space, and certainly seem oblivious to the presence of the mythological figures. This suggests that Titian already understood the issue of mythological space in terms of different time frames - now and the past - that might coexist in one pictorial space. Even so the study of mythological space itself has rarely attended to the ways the space of mythology works, and certainly not the ways this was disrupted in the seventeenth century. My aim is to explore how the very structure of mythology begins to address the enormous changes brought about in the production and circulation of painting. Titian's pictorial space may not challenge the notion of mythological space as a separate, elite space, yet his pictorial strategies reveal a deep engagement with the inherent problem of mythological space. Although Titian produces this mythological space through oil on canvas rather than fresco painting, the artist still manages to 
maintain claims of permanence. But mobility of oil painting through private collections was a factor in Venetian traditions of mythological painting, and for this reason mythological subject matter starts to change in unpredictable ways.

What I want to ask is how did early modern mythological painting confront changes in the production and value of painting with the emergence of the art market? What does it mean to rupture a sense of permanence and fantasy that had literally come to define mythological painting? What are the implications introducing time to a form of painting that seeks to manipulate time and turn it into a strategy of concealment? The spatial disruption of early modern painting is a subject that has received considerable attention in recent years. ${ }^{2 \mathrm{I}}$ Mythological painting remains somewhat outside these debates, yet spatial relations lie at the centre of what was at stake for mythology. Victor Stoichita's study of spatial rupture of early modern religious painting may not directly comment on mythological painting but I take his study as a crucial starting point to think about the issue of disruption of mythological space in seventeenth-century painting. Existing scholarly literature on mythological painting tends to consider the pictorial space as a space for visual poetry where narrative content is articulated. Indeed, due to the dominance of Ovid's Metamorphoses as a source for mythological painting, the pictorial space is full of transformative potential but always in terms of bodies, human or otherwise. There have been numerous studies that focus on how these stories of transformation, from classical myth, are visually depicted in painting. This has led to studies of mythological painting as if it is 'visual storytelling'. ${ }^{22}$

Louis Marin, in his attempts to define the space of Thomas More's Utopia, compares utopia to mythological space and, in the process, argues that the structure of mythological narrative is too loose to articulate a coherent overall meaning of an image. ${ }^{23}$ By bringing spatiality into the equation and allowing a play of exchange between narrativity and spatiality, we only ever approach a provisional meaning in mythological space ${ }^{24}$ Marin argues that a narrative sequence does not work for mythological space, precisely because it is the potential within transformative forces that forges this space. A narrativeoriented approach to interpreting mythological painting is problematic in that mythology, when painted, is different from mythology when written. ${ }^{25}$ In this respect mythological space is, according to Marin, similar to utopic 
space. Both are distant, unreachable, imaginary spaces, which continue to stimulate thinking about how to respond to the existing situation. ${ }^{26}$

Svetlana Alpers argued that seventeenth-century painting could operate between the Italian tradition of 'narration' and the Northern tradition of 'description'. ${ }^{27}$ While Alpers's dualist formulation has been questioned, she crucially introduced the idea of a rupture between two modes of representation in which each is shown to be aware of, and responds to, the other. Within art history, the narrative-oriented approach has been challenged by scholars such as Elizabeth Cropper and Thomas Puttfarken and invariably it is due to the illegibility of the pictorial space of mythology. ${ }^{28}$ An important contribution was made by Puttfarken. He argued for a different notion of pictorial space in the early modern period, and suggested that pictorial space was conceived in terms of the human body, not as narrativity, but as connectivity. ${ }^{29}$ Thus the links between bodies, and the networks of animation that these bodies produce, forged the idea of pictorial space. This is not a rationalized abstracted notion of space, but a space produced through its use by the body and its extension. ${ }^{30}$

\section{The invasion of the everyday}

The most productive point of departure for my study has been Victor Stoichita's notion of split painting. In the much-discussed Self-Aware Image, published in I993, Stoichita argues for the rupture of the very structure of early modern pictorial space. Linking traditional and new forms of painting, Stoichita proposes a more self-conscious understanding of the interrelation between different forms of painting. For the first time the claim was made that the fate of traditional religious imagery was entirely tied to new forms of market painting. Stoichita suggests that the issue of spatiality is crucial, particularly the construction of pictorial space as a mode of rethinking the relation between new forms of representation and their inter-referentiality. For instance, in Pieter Aertsen's Christ in the House of Martha and Mary (c. I 552), he starts from the many ways in which the everyday boldly enters the painting. The objects of the kitchen, the meat, the bread, the pots, the open cabinet, and much more have entered the image and form a frame around the religious subject, which has receded in space. ${ }^{3 \mathrm{I}}$ It is the everyday that produces a split, and in the process produces a dialogue about painting, its traditions, and its changing futures. The incursion of objects from everyday life to the point of 


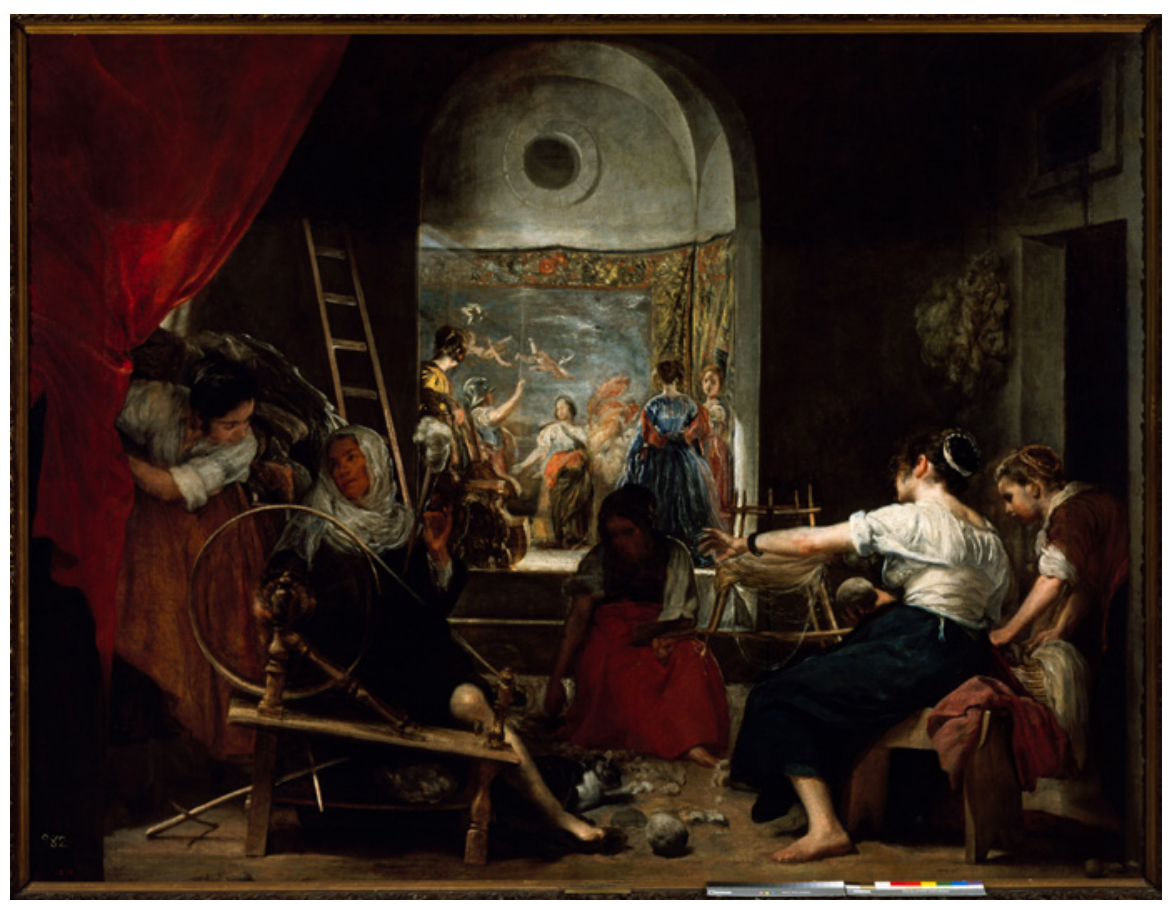

Figure 3 Diego Velázquez, Las Hilanderas, c. I658, oil on canvas, I67 $\times 252 \mathrm{~cm}$, Museo del Prado, Madrid. (C) Courtesy of Meseo del Prado, Madrid. Photo: Scala, Florence.

overwhelming religious subject matter brings into tension established forms of painting with the everyday imagery of marketable painting. Mythological painting is outside of Stoichita's purview, but it is well worth considering his argument in relation to mythological space, which as I have been trying to suggest was already laden with spatial complications.

My main case study, which considers the unsettling of mythological space through the incursion of the everyday, is Diego Velázquez's Las Hilanderas, painted around I658 in the court of Phillip IV of Spain (figure 3). As its popular English title, The Weavers, suggests, the subject does not seem to be mythological, yet it is almost the culmination of the complications of mythological space. In this image two very different types of painting seem to coexist in the same pictorial space: in the foreground, a scene of physical labour that is consistent with a new form of painting directed to the new art market, known generally as genre painting, and which holds its links to the 
so-called 'real' world. In the background, the mythological contest recounted in Ovid's Metamorphoses between Minerva and Arachne about who was the greatest weaver. Interestingly enough, the specificity of the mythological story, in which Minerva loses the contest but turns Arachne into a spider, was for some time forgotten, and it is only relatively recently that its evocation of Titian's mythological paintings was once again recognized. The Spanish court held the most celebrated collection of Titian's mythological painting, including The Rape of Europa (c.1562). ${ }^{32}$

As with Domenichino's frescoes, the scene is presented as a revelation, as something revealed by the drawing back of a red curtain that, until then, concealed what was behind it. With the gesture of opening, as Marin discussed, the mythological space of this painting is seemingly associated with the unimaginable and unexpected. However, instead of mythological imagination, we are presented with the visualization of manual labour. What is now visible, from behind the red curtain, is the attentive work of women weavers in the endless process of making thread out of bits of fleece. It is worth restating that the court, taken as a surface of representation, does not reveal the labour that underlies it: the court is frequently evoked as a world of magic produced through the divine person of the king, who is able to make things appear and disappear at will. ${ }^{33}$ The same is also the case with the making of the painting, with the artist's magic hand only able to exist, ironically, by disguising its labour. To reveal one's labour, especially manual labour, might be compared to the magician giving away his trick. ${ }^{34}$ Yet labour at the level of materiality is precisely what the curtain reveals. We are confronted with a scene of everyday labour. A group of women is immersed in bodily work: their limbs are intertwined and their hands create a rhythmic flow. Everyone is linked by touch and each material is connected and has relation to another. The light from the window on the left behind the curtain highlights the materiality of flesh as much as the materiality of wools and silk. The bare feet of the women rest stably on the ground, emphasizing this physicality. The presence of materiality accumulates; bodies and stacks of cloth and wool intersect.

Las Hilanderas represents the process of the making of material objects. We cannot definitely 'name' what is 'represented' in the foreground, or what we see there. The foreground is a space filled with matter, a world of becoming, 'before' the emergence of the object. Though we certainly see 
objects in the foreground, we also see something coming into being: not a thing but also not nothing. If we see this as the process of making thread, and not the process of weaving tapestry, we encounter a stage before visibility, before becoming visible in pictorial space. Is this perhaps a way in which the material world is brought into a tenuous visibility? Is this what is going on in Domenichino's image of the objects of everyday life before they become a still life and thus an image of art?

Materiality in the scene of everyday life is a crucial aspect of Stoichita's argument about the inverted structure of early modern split painting. For Stoichita the process of splitting brings with it issues of the relation between materiality and the changes in the categorization of painting. The weavers in the foreground, dominating the whole pictorial space, can be connected in some way to the mythological space of the background, but what is the relation between the two? The threshold between the space of myth in the background and the space of everyday life in the foreground is marked by a woman in a pink dress whose glance marks a point of intersection. At the edge of the world of mythology, what does this woman see but the image of labour itself, which cannot exist in her world of magic. For her, the scene of labour is at the edge of her world, but for us, the scene is overtly present and revealed as bodily and connected with the matter that constitutes the raw material of the weavers's work. Like a spider, the bodies in Las Hilanderas are producing a thread, making something new, and forming new links between different kinds of pictorial space.

At this point it is important to point out the crucial differences between this painting and Domenichino's frescoes in the ways they unsettle the space of mythology. Both may interrupt the autonomy of mythology with the everyday, but they draw on very different strategies and effects. In Las Hilanderas, an oil painting, the prestigious link between mythology and architecture has been broken, but it draws on the relation between different kinds of painting and thus extends its sphere of operation. Mythological space cannot hold together the surface of Velázquez's painting but it can participate in a dialogue with other kinds of painting, governed by its own rules of pictorial space with a less clear link to architecture. While, in this case, the splitting of the pictorial space is what brings about the mobility of mythological painting, Domenichino's frescoes depend on their permanent setting to reveal their layering effects. Once the fresco is detached from 
its original setting in the villa, we lose a sense of how the representational layering works to reflect its illusionistic construct, and we also lose a sense of just how far outside the privileged, courtly space the figure of the dwarf turns out to be.

\section{The body and the destabilization of the architectural frame of mythology}

I now turn to one of the most important early modern mythological cycles, in which architecture, fresco and mythology meet. I refer to the late sixteenth-century frescoes by the Carracci brothers in the Gallery of the Farnese Palace in Rome (figure 4). ${ }^{35}$ The Farnese Gallery is always discussed as a model for a new kind of 'grand' fresco in which mythological space is forged from the interconnection of architecture and fresco painting. ${ }^{36}$ The limited scholarly discussion about the frescoes rarely moves away from the

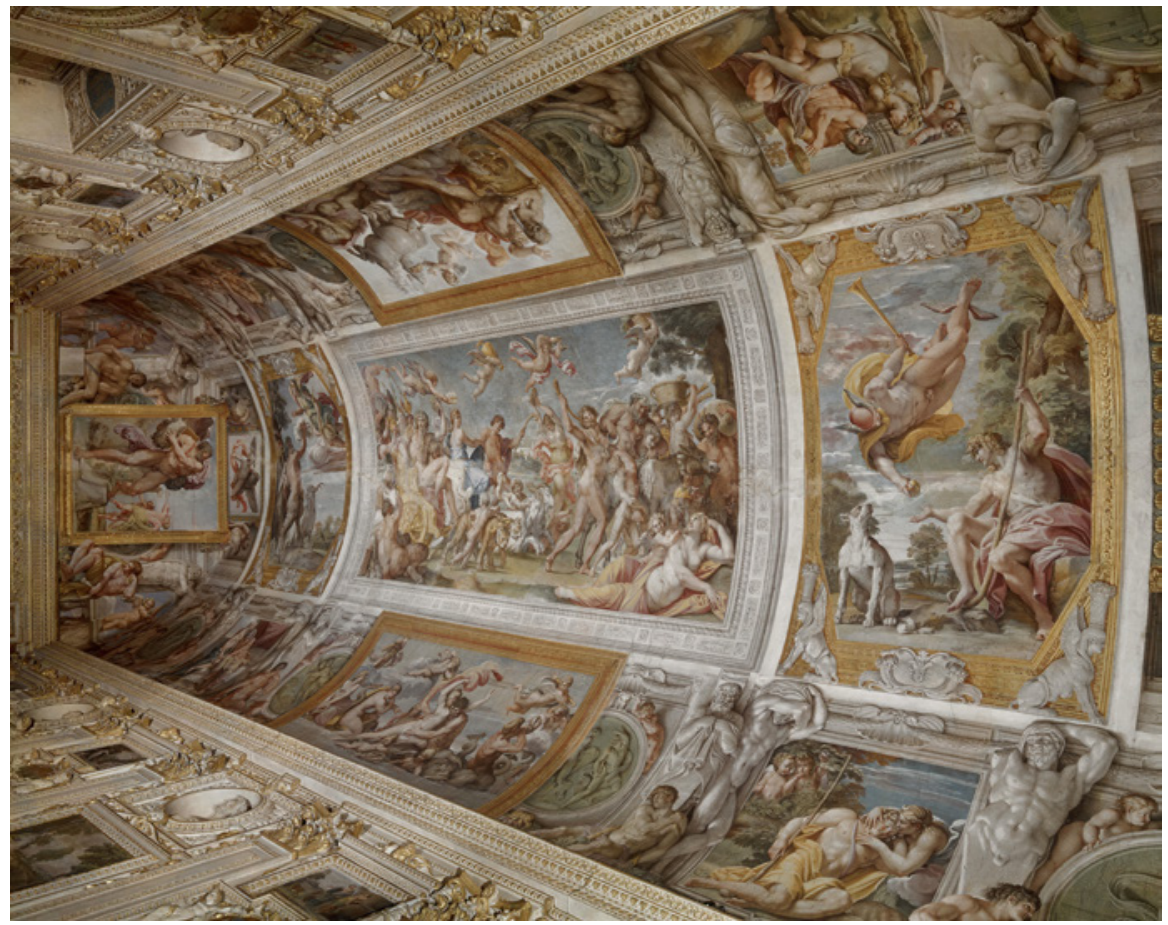

Figure 4 Annibale Carracci, Fresco Cycles of The Farnese Gallery, c. I597, fresco, Palazzo Farnese, Rome. (C) Courtesy of Palazzo Farnese, Rome. Photo: Scala, Florence. 
idea that this cycle became a kind of last stand of private fresco decoration, in large part because in the last century the Farnese Palace has been used as the French Embassy and access to it has been very limited. My intention is not to undertake a comprehensive study of the Farnese Gallery but to focus on how the frescoes redefine mythological space, and do so by articulating a relationship to new forms of painting while seeking to retain fresco's primacy among the arts. For this reason I focus on the innovative forms of framing through which the frescoes restructure mythological space as a space in which permanence and transition are in dialogue. In discussing these earlier frescoes after the works by Domenichino and Velàzquez, it is my proposition that the innovative aspects of these frescoes only become fully evident once the space of mythology had been disrupted through the layering and splitting of pictorial space.

It is usually acknowledged that these frescoes signal a rupture in the traditional system of patronage, even if their relation to the emergence of the art market is ignored. The Carracci brothers were brought to Rome to undertake a prestigious commission, yet were constantly at odds with the patron's demands and restrictions about what work they could undertake. ${ }^{37}$ All that is known about the commission is from a letter from Cardinal Odoardo Farnese to his brother that states his intention to undertake frescoes in honour of the military activities of their father. This plan changed: instead of the intended historical cycle, the Carracci brothers executed a mythological cycle based on Ovid's Metamorphoses, and instead of the central reception rooms of the palace the decoration was carried out in the more informal galleria at the back of the palace, facing the garden. ${ }^{38}$

In the Farnese Gallery, pictorial space seems 'compressed' by the imposing presence of real and illusionary frames. The height of the gallery is considerable and the lower wall is articulated with niches in which life-size classical sculptures are displayed. The false architectural frames painted on the barrel-vaulted ceiling extend the existing architecture and create a perception of limitless space. While the mythological stories emerge vividly, it is the framing of these stories that is striking and is used to distinguish between different kinds of painting. The architectural framing mixes architectural forms with antique sculpture, as in the scene of Jupiter and Juno. The picture frame at the center of the ceiling is painted to resemble molded white architectural frames of the kind used in ceiling decoration in Venice showing 
a Titian-like Bacchanal, where instead of fresco painting, wall decoration consisted of inserted framed pictures.

Reflection on the nature of painting's conjunction with architecture does not, however, extend simply to forms of painting used within architecture. Annibale Carracci addresses the new art market's valorization of painting by having scenes set within gilded frames that appear to be oil paintings. These were known as quadri riportati ('transport' paintings), and as Bellori observes, Carracci's masterful illusionism is especially apparent in the representation of oil painting with fresco, and these paintings, one in each of the four walls, seem to have been raised from a lower position, supported by Ignudi, putti and herms. ${ }^{39}$ Spatially, these ostensible oil paintings stand in contrast to the four paintings that are defined as fresco that exist as if part of the architecture..$^{40}$ The bronze medallions - framed as metal circular mirrors - are located around the lower tier of the ceiling, and some are behind the quadri riportati. The layering seems to push the fresco paintings further back on the wall and the oil paintings, further forward. As a result, the frescoes appear permanently attached to the wall while the oil paintings look as if they could, quite literally, be carried away.

As innovative as this inclusion of portable painting within a fresco decoration is, it is the use of the human body as a framing device that seems to bring a new transformative potential to the mythological space. The body as frame conveys the idea of body as flesh, as material and thus with the potential to be embodied in terms of mobility, time and change. ${ }^{4 \mathrm{I}}$ From the preliminary drawings, it is clear that Carracci uses the body as a connecting device, creating a space by bringing together different elements (figure 5). This is a departure from the convention of the clear boundary between the body in the picture and the body in the architectural frame. In this drawing, Carracci even chose to start the composition with a framing figure instead of the figures in the narrative space. Moreover, the traditional notion of mythological narrative (in which bodies are characters within each scene to be 'contained' and ordered to ensure a coherent reading) is disrupted by the use of framing figures. Instead, in Carracci's final composition, there is an opening of an in-between space, which is neither narrative nor frame. The development of this in-between space, particularly the insertion of the body and onto the frame of pictorial space, disrupts the coherence of mythological space. 


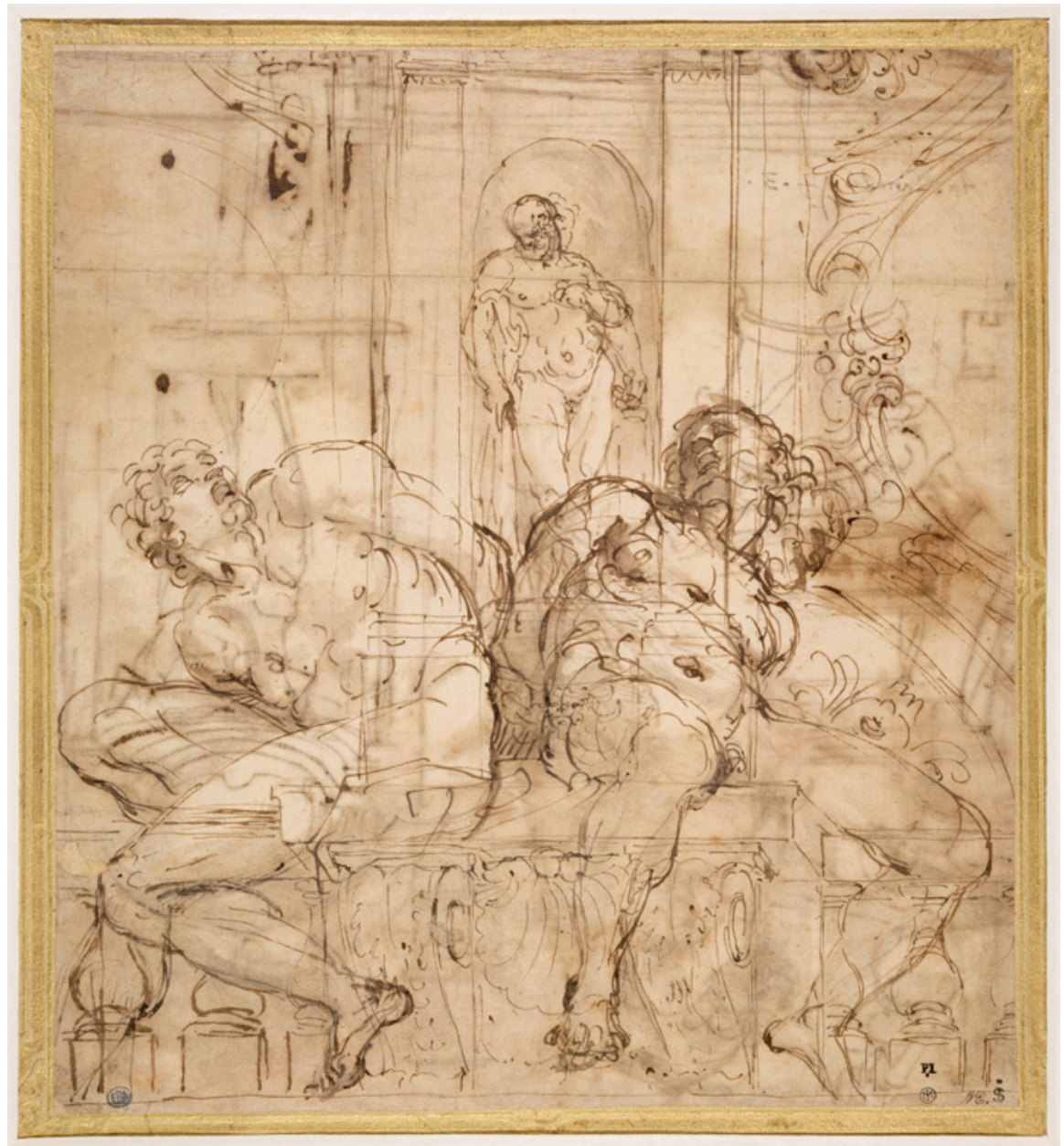

Figure 5 Annibale Carracci, Design for the Farnese Ceiling. c.I 597, drawing, École des Beaux-Arts, Paris. (C) Courtesy of École des Beaux-Arts, Paris. Photo: Agence Photographique de la Réunion des Musées Nationaux et du Grand Palais, Paris.

A remarkable diversity of figures serve, as is usual, to support the framework; some are sculptural, others painted, some of stone, others of flesh and blood; some human, others hybrids between architecture and human, between human and divine. Sitting, sliding, lying and twisting in various positions, the figures are a kind of commentary on the traditional conjunction between architecture, fresco and transformation in painting. Around the grand 
golden frame for Polyphemus Furioso, for example, there are two herms, half architectural and half human, their arms locked in an embrace as if seeking to detach themselves from the walls to which each belongs (figure 4). Next to these herms, there are a cluster of framing figures including two putti and two painted nudes, and two sculptural herms around a medallion of the Flaying of Marsyas. It is as if these figures are 'peeling back' the pictorial space they occupy by revealing different 'skins' of representational layers for the body. The ignudo to the right of the medallion seems to have forgotten his duty to hold the frame and, like the others, is separating from the architectural structure. Next to the ignudo, there is a sculptured figure with his face covered by drapery (figure 4). Not only is the drapery an extension of the curtain inside the narrative scene, but the covering wittily prevents the framing figure from seeing the amorous encounter of Jupiter and Juno. The framing figure opens the fresco to its frame, and loosens the architectural hold. In The Sleeping Endymion the frame is provided by a full figurative sculpture and a herm with its right arm broken-off, as if to suggest that it is returning to the raw material from which it is made (figure 4).

In the Farnese Gallery, the eye is free to wander. The embodied frame brings mobility to the pictorial space instead of retaining the clarity of an abstracted surface. Carracci's suggestive spatial arrangement of dividing and re-directing the relation between body, frame and wall surface can be interpreted as a counter claim to the notion of oil painting as the most experimental, mobile form of art. Indeed, fresco is able to extend its selfreflexive relation to the architecture while representing a new possibility for 'transportable' painting. In Las Hilanderas, mythological space is invaded from the outside, while in Domenichino's Apollo cycle it is ruptured from within, by revealing its lack of depth. In the Farnese Gallery, however, fresco confronts the challenge of new painting by showing itself able to absorb innovations outside the tradition of courtly painting, and drawing on both the layering of pictorial space and the splitting of the surface. The framing figures split the whole surface of the ceiling not only into different kinds arts - oil painting, fresco painting, sculpture, metal relief - but also into different styles of art: Roman, Venetian, Florentine.

I have attempted to investigate how the disruption of mythological space operated in the seventeenth century and how it offered a counter discourse about the modernity of painting. Thus far, in my study, what has emerged 
is how mythological fresco's own vocabularies, particularly vocabularies of concealing and revealing, were used to assert its own tradition while simultaneously claiming innovation and mobility. The disruption of the structure of pictorial space, which I have suggested operated differently in mythological oil painting and in mythological fresco painting, points to new possibilities for mythological space in relation to other worlds. These possibilities prove to be more radical than Marin envisioned, for mythological space now had to deal with the world of the everyday.

\section{Notes}

I would like to thank my supervisor Rose Marie San Juan, as well as Mechthild Fend and Caspar Pearson for their feedback. I am also grateful for the permission of Prince Aldobrandini and the assistance of Antonella Fabrian Rojas, which enabled me to conduct research at the Villa Aldobrandini in Frascati. Funding for this project was generously provided by an Overseas Bursary in the Department of History of Art at University College London.

I Louis Marin, Utopics: The Semiological Play of Textual Spaces, trans. Robert A. Vollrath, NJ, I984, p. 33 .

2 Luigi Salerno, 'A Domenichino Series at the National Gallery: the Frescoes from the Villa Aldobrandini', in The Burlington Magazine, vol. I05, no. 722, I963, p. 195.

3 David Coffin, The Villa in the Life of Renaissance Rome, Princeton, I979, p. 43, p. I 42.

4 Anthony Blunt, 'Illusionist Decoration in Central Italian Painting of The Renaissance', Journal of the Royal Society of Arts, vol. I07, no. 5033 (April I959), pp. 309-3 Io.

5 Apollo Killing Cyclops is the only exception to the use of Ovid's Metamorphoses. The source may have been Apollodorus' Library III, x, 4. See Richard Spear, Domenichino, London and New Haven, I982, p. 198.

6 Coffin, op. cit., p. 98, p. I03, pp. 250-252, p. 329, p. 328.

7 Ibid., p. II, p. 2 I, p. 98 , p. IO3, p. I87, pp. 250-252, p. 329 , p. 358.

8 Ibid., p. 24I, pp. $245-249$. Transformation was not left only to the visual. The space would have resonated with sound from a hidden water organ in the room, and from the nearby outdoor water theatre.

9 Spear, op. cit., p. 197.

Io Malcolm Bull, The Mirror Of The Gods: Classical Mythology In Renaissance Art, Oxford, 2006, p. I8, p. 34; Elizabeth Cropper and Charles Dempsey,' Italian Painting of the Seventeenth Century', The Art Bulletin, vol. 69, no. 4 (1987), p. 494; Maria Loh, Titian Remade, Los Angeles, 2007, p. 89.

I I Spear, op. cit., p. I98.

I2 Touba Ghadessi, 'Lords and Monsters: Visible Emblems of Rule', I Tatti Studies in the Italian Renaissance, vol. I6, no. I/2 (September 2013), pp. 49I-492; Erin Griffey, 'Multum in parvo: Portraits of Jeffrey Hudson, Court Dwarf to Henrietta Maria', 
The British Art Journal, vol. 4, no. 3 (Autumn 2003), p. 40, p. 46; Esther Cadahía and Victoriano Roncero López, 'The Court Jester in Sixteenth and Seventeenth Century Spain', South Atlantic Review, 2007, p. I05; Salvador Salort and Susanne Kubersky-Piredda, 'Art Collecting in Philip II's Spain', The Burlington Magazine, 2006, pp. 660-66I.

I 3 The fresco was completed by students of Raphael (Giulio Romano, Giovanni Francesco Penni and Raffaellino del Colle), following his drawings, and only after his death. See, Levey, op. cit., p. 29.

I4 Passeri in Spear, op. cit., p. I98.

I5 A life study at Windsor Castle is known as the only drawing for the frescoes by Domenichino.

I6 Passeri in Spear, op. cit., p. I98.

I7 Ibid., p. I98.

I8 Levey, op. cit., p. 29.

I9 Coffin, op. cit., pp. Ioo-Ior; Victor Stoichita, Self-Aware Image: An Insight into Early Modern Meta-Painting, trans. Anne-Marie Glasheen, Cambridge, I996, pp. 7-IO.

20 Salerno, op. cit., p. I96; Stoichita, op. cit., p. 29.

2 I Svetlana Alpers, 'Interpretation Without Representation, Or, The Viewing of Las Meninas', in Representations, vol.I, no.I, I983, pp. 37-38; Alpers and Michael Baxandall, Tiepolo and the Pictorial Intelligence, New Haven, I996, p. I0; Jan Baptist Bedaux, p. 296 and pp. 302-304; Elizabeth Cropper and Charles Dempsey, 'Italian Painting of the Seventeenth Century', The Art Bulletin, vol. 69, no. 4, I987, p. 507; Thomas Puttfarken, The Discovery of Pictorial Composition: Theories of Visual Order in Painting, 1400-1800, New Haven, 2000, pp. 3-7; Stoichita, op. cit, pp. 3-5, pp. I7-I 8; Cropper and Dempsey, Nicolas Poussin, Princeton, I996, p. 9, pp. 42-48, p. I8I.

22 Otto Brendel, 'Borrowings From Ancient Art in Titian', in The Art Bulletin, vol. 37, no. 2, I955), p. I I3; David Rosand, 'Ut Picto Poeta: Meaning in Titian's Poesie', in New Literary History, 1972, pp. 532-533; Rosand, 'Titian and The Eloquence of Brush', in Artibus et Historiae, vol. 2, no. 3, I98 I, pp. 85-86.

Marin, op. cit., p. 33 . Ibid., pp. 34-35.

25 Ibid., pp. 55-56.

Marin, 'Frontiers of Utopia', in Critical Inquiry, vol. I9, no. 3, I993, p. 406. Svetlana Alpers, The Art of Describing, Chicago, I983, pp. 38-39. Alpers, 'Interpretation Without Representation, Or, The Viewing of Las Meninas', in Representations, vol. I, no. I, I983, pp. 37-38; Cropper and Dempsey, 'Italian Painting of the Seventeenth Century', The Art Bulletin, vol. 69, no. 4, I987, p. 507; Puttfarken, op. cit., p. 7.

Puttfarken, op. cit., p. 7, pp. 59-60, pp. 69-70, p. I73, p. I83. Ibid., pp. 59-60, p. 69, p. 70, p. I73, p. I83.

3 I Stoichita, op. cit., pp. IO-I3, pp. I7-I 8.

32 Alpers, The Vexations of art: Velázquez and Others, New Haven and London, 2005, pp. I96-I97; and Bedaux, op. cit., p. 296 and pp. 302-304; Jonathan Brown, Velázquez: Painter and Courtier, New Haven, I986, p. 2 I. 
2009, p. 22, p. 97; Aneta Georgievska-Shine, 'From Ovid's Cecrops to Rubens's City of God in The Finding of Erichthonius', The Art Bulletin, vol. 86, no. I (Mar., 2004), pp. 67-68; Emily Umberger, 'Velázquez and Naturalism II: Interpreting Las Meninas', RES: Anthropology and Aesthetics, no. 28 (Autumn, I995), pp. IоO-IоI.

34 Jan deVries, 'Luxury and Calvinism: Supply and Demand for Luxury Goods in the Seventeenth-Century Dutch Republic,' in The Journal of the Walters Art Gallery, vol. 57, I999, pp. 73-85; Stoichita, op. cit., p. I02.

35 Clare Robertson, The Invention of Annibale Carracci, Milan, 2008, p. I6.

36 Rudolf Wittkower, Art and Architecture in Italy 1600-1750, New Haven and London, I985, p. 57.

37 Cropper and Dempsey, op.cit., p. 503; Robertson, op. cit., p. I9; Spear, op. cit., p. I3.

38 Charles Dempsey, Annibale Carracci and the Beginnings of Baroque, New York, I977, pp. 363-364; Robertson, op. cit., pp. I46-I47; Walter Vitzthum, 'Two Drawings by Annibale Carracci in Madrid and a Comment on the Farnese Gallery', in Master Drawings, vol. 2, no. I, I964, pp. 45-49.

39 The paintings are Poluphemus Innamorato and Polyphemus Furioso on the short walls, and Venus and Triton and Aurora and Cephalus on the long walls.

40 Dempsey, op.cit., p. I2.

4I Amerila Jones, 'Body', in Critical Terms for Art History, Robert S. Nelson and Richard Shiff (eds.), Chicago, I996, p. 25 I. 